\title{
Modeling Unsaturated Zone Water Movement in the Floodplain Wetlands of the Volta Basin
}

\author{
Benjamin Kofi Nyarko ${ }^{1}$ \\ ${ }^{1}$ Department of Geography and Regional Planning, University of Cape Coast, Cape Coast, Ghana \\ Correspondence: Benjamin Kofi Nyarko, Department of Geography and Regional Planning, University of Cape \\ Coast, Cape Coast, Ghana. Tel: +23-32-0664-0183. E-mail: bnyarko@ucc.edu.gh
}

Received: March 2, 2020

Accepted: March 24, 2020

Online Published: July 1, 2020

doi:10.5539/enrr.v10n3p1

URL: https://doi.org/10.5539/enrr.v10n3p1

\begin{abstract}
The unsaturated zone of floodplain wetlands in the White Volta River basin provides an inextricable link between basin hydrology and the sustenance of plant growth. The HYDRUS-1D model was used to derive water budgets and to estimate fluxes to understand the hydrological complexities of these wetland systems. The model result indicates Spatio-temporal variation in the volume of vertical fluxes. In 2005, the estimate for average simulated flux was $0.29 \mathrm{~cm} /$ month in June and $1.23 \mathrm{~cm} /$ month in July. Consequently, the hydraulic head increased from $138.94 \mathrm{~m}$ to $139.30 \mathrm{~m}$ for the period from June to July 2005. For all sample sites, the increase in hydraulic head occurs within July and October, coinciding with high surface water fluxes. From the calculated water balance, the average monthly estimate of bottom flux was $0.01 \mathrm{~cm} /$ month for 2004 and $1.1 \mathrm{~cm} /$ month for 2005 . The flow through the unsaturated zone and discharging into the subsurface water system has a high dependency on both the soil structure and the volume of water infiltrating through the surface; the highest discharge is within the period of highest water input.
\end{abstract}

Keywords: Unsaturated Zone, Groundwater Recharge, Floodplain Wetland, Infiltration

\section{Introduction}

The unsaturated zone in floodplain wetlands in sedimentary formation with well laid down structure represents a zone of importance to ecological and hydrological processes. It controls the interaction between vadose and saturated domains. Despite the importance of these processes, human activities and climate change threatens floodplain wetlands. Hydrological processes such as infiltration, capillary rise, and interflow taking place in the unsaturated zone of floodplain wetlands are of importance to flow pathways and moisture dynamics. The unsaturated zone receives water from local precipitation or over bank flow, and stores and redistributes it to subsurface and adjacent landmass (Mertes, 1997; Woessner, 2000). However, the redistribution of water in the soil is dependent on the material properties and internal structure of the unsaturated zone, with its attendant impact on flow paths, residence time, mobilization of potential containments, and nutrients. In the research of Ravi et al. (1998) and Bradley and Gilvear (2000), they observed a high correlation between saturation levels and hydraulic properties of soil (e.g., porosity) during the rainy season and application of water. The heterogeneous nature of subsurface structures makes it difficult to estimate soil water fluxes using standard hydrological methods. Installing sensors and other invasive tools to study or estimate fluxes further increases heterogeneity (Bradley \& Gilvear, 2000). Consequently, the protection of wetlands requires an understanding of the mechanism controlling the hydrological processes.

Undertaking any form of activity on floodplain wetland requires knowledge of, structure of the landscape, unsaturated zone, floodplain hydraulic processes, and a review and measurement of different controlling factors (Ravi et al., 1998; Riddell et al., 2012; Liang et al., 2018). The controlling factors of hydraulic and flow processes in the unsaturated zone fall into two main groups: climatic factors and landscape (topo sequence) factors. Flow processes in the unsaturated zone bring about changes in the state and content of soil water that is complicated to depict quantitatively. Such changes involve complex relations between soil hydraulic properties. The formulation and solution of unsaturated flow problems often require the use of models and indirect methods of analysis, based on approximations or numerical techniques (Simunek et al., 1996; Mansell et al., 2000; Simunek et al., 2016). For instance, a partial differential equation in the model describes the movement of water through unsaturated porous media, stating initial and appropriate boundary conditions (Wang et al., 2006; Vogel \& Ippisch, 2006). 
Mansell et al. (2000) noted that a multidimensional numerical model could be used to simulate flow in a wetland. Most of the numerical models establish a connection between unsaturated soil zones' groundwater and ponds (Trepel \& Kluge, 2004; Sriwongsitanon et al., 2009). In some research work, water movement in the unsaturated zone of wetlands, UNSAT1 model, a Hermitian finite element model is used to simulate one-dimensional nonhomogeneous soil profiles (Bradley \& Gilvear, 2000). In other examples, HYDRUS-2D has been used to model seasonal soil moisture dynamics in groundwater-fed wetlands and water flow (Joris \& Feyen, 2003). In this study, an attempt was used to assess changes in floodplain depressions and hydrological boundary conditions and their effect on vegetation-related subsurface groundwater parameters. Also, consideration is given to soil heterogeneity interface with hydrological processes within the unsaturated zones, and its contribution to groundwater recharge.

Studies of wetland hydrology have focused on assessing wetland water budgets (Bradley \& Gilvear, 2000). The assessment of wetland water budgets and their hydro-periods neglects the importance of the unsaturated zone. Unsaturated zones of wetland in the sedimentary formation of the White Volta River basin have a marked temporal and spatial variability of water fluxes. However, only a fraction of the entire system gets saturated throughout the year (Nyarko, 2007). The response of the unsaturated zone to rainfall events is a reflection of textural composition, hydraulic conductivity, moisture retention, and evapotranspiration.

Over the past years, government policies are towards harnessing wetlands' economic value for various activities such as crop cultivation, fisheries production, and wetland ecology restoration. The wetlands in the White Volta River basin exhibit Spatio-temporal variability, through the interplay between meteorology, hydrology, and the surrounding system (Nyarko, 2007). More also, the interaction between groundwater and surface water is dominant in the wetland (House et al., 2016). The functioning of these wetlands for groundwater recharge, soil moisture retention, nutrient retention, and agricultural activities makes knowledge of the hydrology of the wetlands indispensable (Brown et al., 2003; Joris \& Feyen, 2003). However, within the White Volta River basin, the seasonal hydrodynamics of the unsaturated zone in the floodplain wetland and its influence on groundwater recharge is poorly understood, thereby affecting its usage for agricultural activities.

In this study, the HYDRUS-1D model is used to simulate the flow of water in the unsaturated zone to gain insight into the complexities of water distribution and the volume of recharge in the floodplain wetland system of the White Volta River basin. HYDRUS-1D is widely used to explore water fluxes in different soil profiles, and its application covers cropland, surface, and groundwater interaction because it is highly adaptive. The objectives for the study are; 1) understand and educate wetland users/conservationists on the hydrological dynamics and complexities of the unsaturated zone of the Pwalugu floodplain wetland, and 2) derive water budgets and estimate fluxes.

\section{Materials and Methods}

\subsection{Description of Study Site}

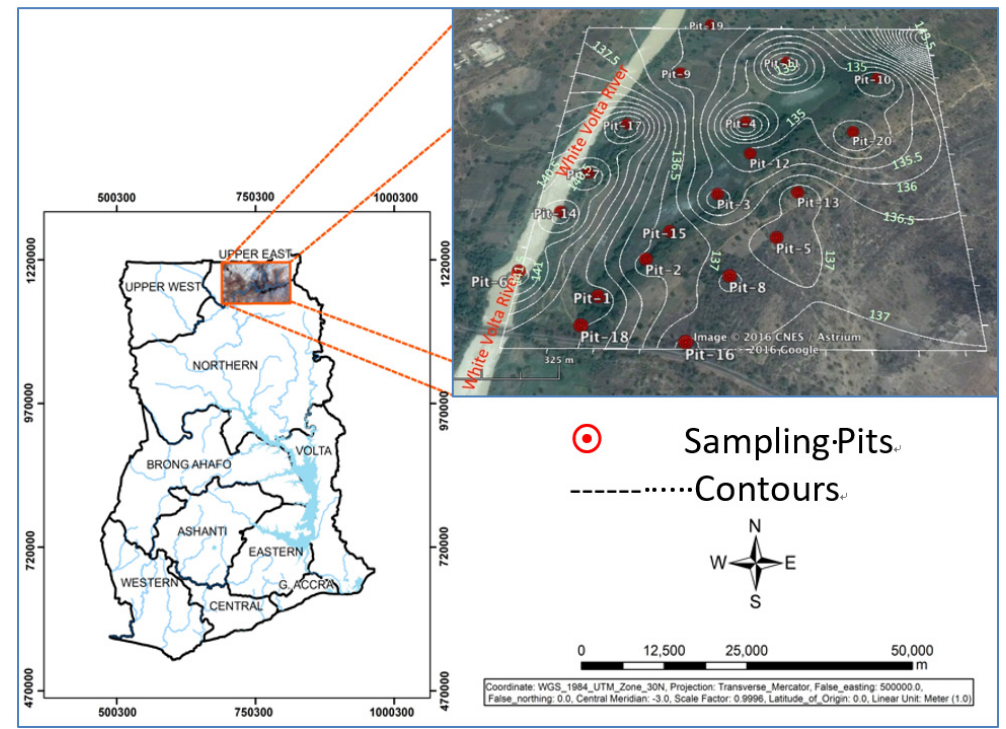

Figure 1. Map showing study site in the White Volta River basin, Ghana (Pwalugu). Location of pits for soil sampling at the Pwalugu floodplain wetland site 
The basis for choosing the Pwalugu floodplain wetland site (Figure 1) is because the government has earmarked it as a pilot site for all year round crop cultivation. Therefore it is prudent to understand the hydrodynamics of the selected site to enable efficient water use. The site falls within the savanna belt, and its climate is the semi-arid type. Three air masses influence it: Eastern continental (E), Tropical maritime (mT), and Tropical continental (cT). The interaction of the air masses depends on the oscillation of the inter-tropical convergence zone (ITCZ). At a point in time, the influence of either $\mathrm{mT}$ or $\mathrm{cT}$ determines the characteristics of the weather. The cT winds are dry and dusty; they mostly occur from November to April, which is the dry season. The temperature within these months ranges between $20 \mathrm{oC}$ and $34 \mathrm{oC}$. Tropical maritime $(\mathrm{mT})$ occurs in the wet season from March to October, exhibiting a high rate of humidity that ranges from $60 \%$ to $90 \%$ at $0600 \mathrm{hrs}$ and $77 \%$ to $78 \%$ at $1500 \mathrm{hrs}$. As a typical semi-arid climate, the potential evaporation exceeds precipitation for 6-9 months. Rainfall in the study area starts in May and ends in October, with an annual total estimated as $1100 \mathrm{~mm}$, of which $301 \mathrm{~mm}$ is within August and September.

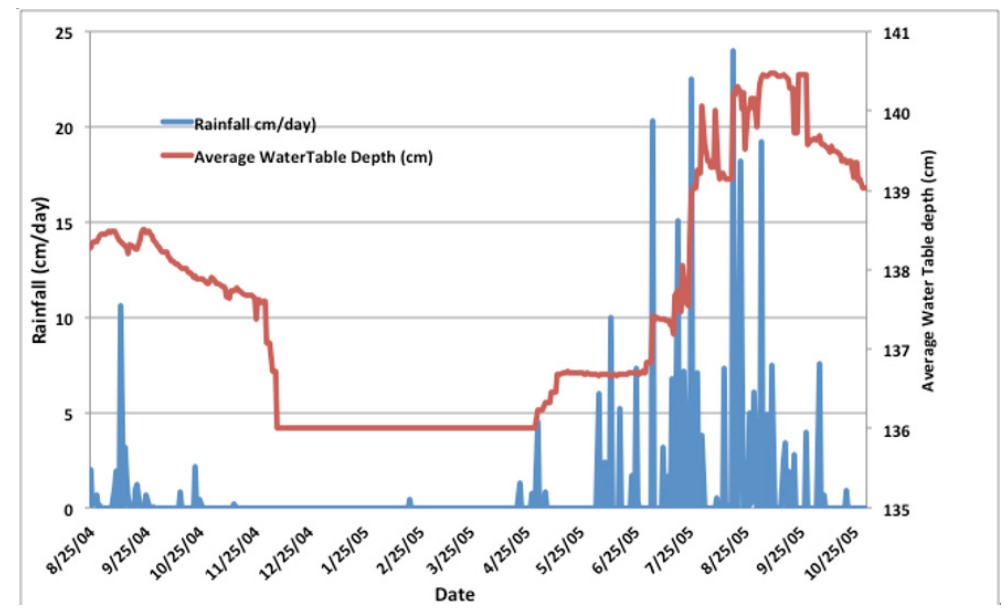

Figure 2. Seasonal variation of rainfall and groundwater table

The Voltaian, Birimian and Granitiods formation are part of the basement rock underlying the Volta catchment (Kesse, 1985). The Voltaian system consists of limestone, arkose quartzite, conglomerate, sandstone, and shale. Additionally, the Birimian system consists of greywacke, metamorphosed lava, tuff, pyroclastic rock, and schist. The faulting in this system tends to follow the folds. Joints in the rocks have different orientations and parallel to the folds. The Granitiods are mostly of the Cape Coast and Bongo series. The Bongo Granitiods consist of porphyritic hornblende and microdine granite, while the Cape Coast series is made up of muscovite-biotite, granite, and potash rich. The Voltaian system is well consolidated and is not inherently permeable, except in a few areas. Soils within the Volta River catchment, are derived from sandstone, schist, granites, alluvial materials, greenstone, andesite, and amphibolites. Specifically, the soils found in the study site are Eutric Fluvisol, Lithic Leptosols, Eutric Gleysols, and Gleyic Lixisols. The soil texture at the study site consists of clay, silty clay, loamy clay, and sandy clay. The mean bulk density and porosity of the wetland soil are $1.48 \mathrm{~g} / \mathrm{cm} 3$ and $43.73 \%$, respectively. The soil profiles (Figure 3 ) of the wetland in the sedimentary formation can be distinguished using their properties and types of horizons. Soils in the Pwalugu wetland sites have distinct horizons, that is A and B-horizons. The soil moisture content varies in the study sites, with high moisture content at a depth of $100 \mathrm{~cm}$, which might be due to capillarity. The highest water table is in September (Figure 2). Between August and October, the wetland has a ponded depth of about $120 \mathrm{~cm}$; it can fall below the surface to a depth of $800 \mathrm{~cm}$ when there is less rainfall. The groundwater table varies with the seasonal rainfall pattern. 


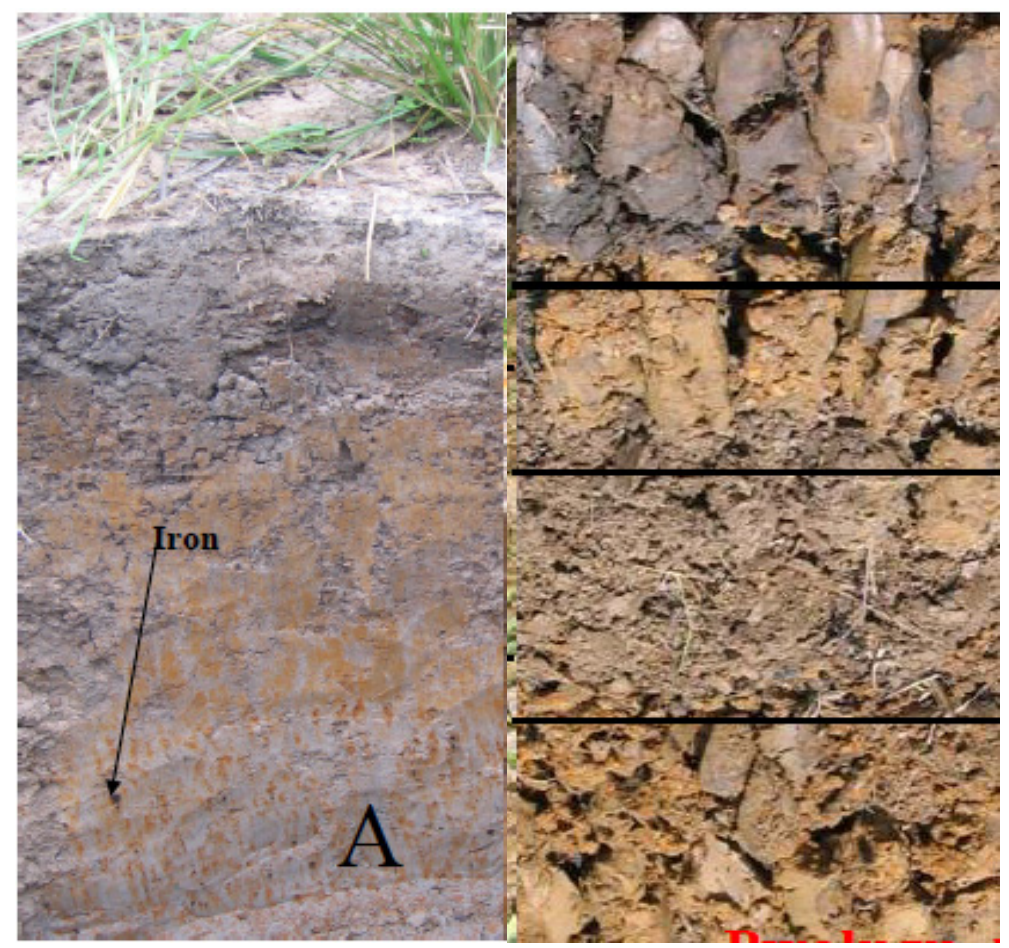

(a)

(b)

Figure 3. (a) soil profile at a depth of $100 \mathrm{~cm}$ showing clay layers during soil profile characterization; (b) Soil profile augured to a depth of $7 \mathrm{~m}$ indicating different layers

To establish the differences in soil horizons properties such as structure, concretion, texture, color, mottle, and root density. The B-horizon is of a sandy clay texture type, and the structure of the soil is medium to moderate sub angular block. In the study site, some of the soils found belong to the Kuapela series; this has high clay content in the B-horizon. Concretion is absent in all sampled points except in areas with a high level of saturation, which had a few iron (Fe) concretions. The B-horizons of soils sampled show signs of illuviation, revealed through a brighter color than in the A-horizon. The A-horizon is at the surface, with a high organic matter accumulation from decomposing vegetal matter.

Vegetation found in the study site is the interior wooded savanna (mid-dry savanna and wet savanna) and Guinea savanna (dry savanna). The distinct vegetation types identified in and around the floodplain wetland depression are Mittragyna inermis, Combretum species, Gardenia Species, and Psuedocedrala species, Afzelia Africana and Diospyros mespilliformis. Some grasses found include Andropogon gayanus var., Bsiqumulatus and Andropogon var., Argyrophues, Pennisetum pedicellatum, and Hhyparrhenia species. The changes in the vegetation of the study area over the years are due to anthropogenetic activities, thereby giving it a different cover characteristic. The sequences of farming practices, coupled with shorter bush fallow, have contributed to the sparseness of tree density.

\subsubsection{Model Theory and Description}

To model the redistribution of rainfall input within the study site, HYDRUS-1D was used (Simunek et al., 1996; Simunek et al., 2016). The HYDRUS-1D model solved Richards' equation and analyzed water movement in unsaturated, partially saturated, or fully saturated porous media in a one-dimensional model using a finite element scheme. In general, Richards' equation is given by:

$$
\frac{\partial \theta}{\partial t}=\frac{\partial}{\partial z}\left[K(h) \frac{\partial h}{\partial z}+K(h)\right]-S
$$

Where $\theta$ is the volumetric soil water content $\left[\mathrm{cm}^{3} \mathrm{~cm}^{-3}\right] ; t$ is time $[\mathrm{d}] ; h$ is the soil water pressure head $[\mathrm{cm}] ; z$ is the gravitational head as well as the vertical coordinate [cm] (upwards is positive); $K(h)$ is the unsaturated hydraulic conductivity [ $\left.\mathrm{cm} \mathrm{d}^{-1}\right] ; S$ a sink term accounting for root water uptake. 
The flow domain of the soil profile is discretize into N-1 adjoining elements, with the ends of the elements located at the nodal points, and $\mathrm{N}$ is the number of nodes. HYDRUS-1D assumes that the direction of the vertical coordinate $\mathrm{x}$ is positive upward. The model permits specification of element grid of the soil profile, specific material properties for each computational node and element in the flow domain. The degree of anisotropy must be assigned. The model handled the lower and upper boundaries of the soil profile. With the upper boundary, atmospheric with surface layer conditions such as rainfall and evapotranspiration were specified at daily intervals, while the lower boundary, the researcher set a free drainage condition.

HYDRUS-1D can derive water budgets and estimate fluxes in any complex landscape system. However, the HYDRUS-1D model's accuracy depends on the assumption and the physical conditions of the site. Hence, the HYDRUS-1D model applied to the study site assisted in partitioning water retention and excess soil water percolating to estimate the amount of recharge into the subsurface water.

HYDRUS-1D uses Richards' equation to parameterize relationships between soil hydraulic properties, soil water retention $\theta(\mathrm{h})$, and hydraulic conductivity $\mathrm{K}(\mathrm{h})$. Additionally, within the model, the van Genuchten-Mualem analytical model (equations 2 and 3 ) is used when a researcher wants to describe and predict soil water retention parameters (Simunek et al.,1998):

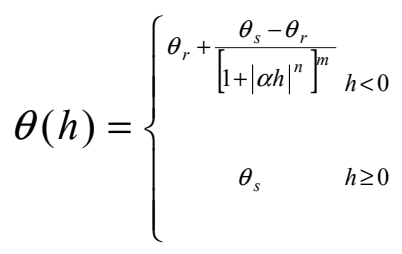

The van Genuchten-Mualem analytical model has five parameters that define the shape of the function: $K_{s}$ is the saturated hydraulic conductivity, $\theta_{s}$ is the saturated porosity of the soil, $\theta_{\mathrm{r}}$ is the residual moisture content, $\alpha$ is the inverse of air entry value (or bubbling potential), and $n$ is a pore size distribution index.

The hydraulic conductivity function in HYDRUS-1D uses the van Genuchten-Mualem pore size, distribution model:

$$
k(h)=K_{s} S_{e}^{l}\left[1-\left(1-S_{e}^{1 / m}\right)^{m}\right]^{2}
$$

Where

$$
m=1-\frac{1}{n}, S_{e}=\frac{\theta-\theta_{r}}{\theta_{s}-\theta_{r}}
$$

Where $S_{e}$ is effective saturation, 1 represents the pore connectivity parameter and the estimated value of 0.5 for most soils.

\subsubsection{Model Setup and Required Input Data}

The simulation of hydrodynamics in the unsaturated zones requires input data relating to the model parameters such as; the geometry of the system, the boundary conditions, for simulating transient flow and initial conditions. Physical parameters to describe the properties of the system under consideration is applied. For the unsaturated zone, these include the soil water characteristic $\theta(h)$ and the hydraulic conductivity $K(h)$. An accurate description of the two hydraulic functions, $K(h)$ and $\theta(h)$, is essential for the representation of unsaturated flow. The hydraulic conductivity decreases sharply as the moisture content reduces from saturation. The experimental procedure for measuring $K(h)$ at different moisture contents is rather tricky and not very reliable. Alternative procedures applied to derive the $K(h)$ function from more easily measurable properties characterizing the soil. In many studies (Simunek et al.,1998), the hydraulic conductivity of unsaturated soil is a function of a nonlinear function of the effective saturation and hydraulic conductivity at saturation. There are other parameters; for example, $\alpha$ is the reciprocal of air entry value $\left(\mathrm{cm}^{-1}\right)$, and $n$ is a pore size distribution parameter. Meteorological data include rainfall, solar radiation, wind speed, humidity, and temperature (minimum and maximum) were from the Navrongo synoptic weather station. Daily evapotranspiration was estimated daily using the modified Penman-Monteith model (Allen et al., 1998). 
The system design is a one-dimensional flow domain, depicted in Figure 4, which extends from the soil surface to the defined bottom of the soil layer. In the model, a finite element grid covering the soil profile was setup. In running the model set up, two main boundary conditions were specified. These were the atmospheric boundary condition with surface layer and free drainage for the lower boundary. During the modeling process, to accurately represent the topography and substrate, initial conditions were selected. The initial textural characteristics for the soil remained constant, and we set a maximum height of $50 \mathrm{~cm}$ for ponding at the soil surface.

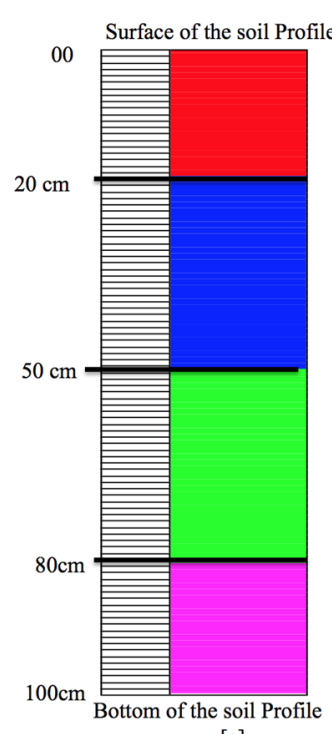

[a]

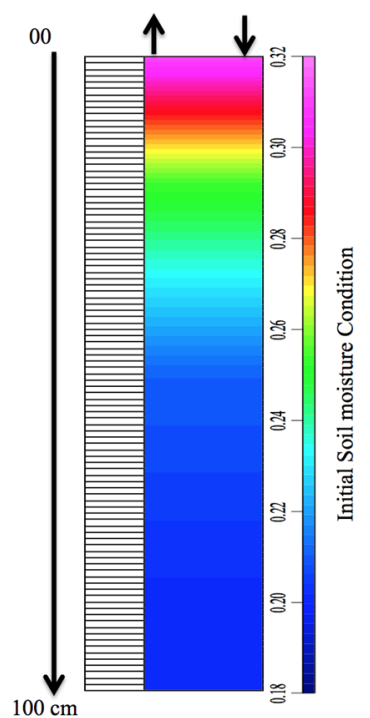

$[\mathrm{b}]$

Figure 4. A view of the field situation of the one-dimensional flow of the soil profile [a] and the initial soil moisture condition specified for Pit $6[\mathrm{~b}]$

\section{Subsurface Water Level Variability}

The wetlands within the White Volta River floodplains are very complex due to different hydro-periods corresponding to the seasonal climatic pattern and spillover from dams upstream. As part of the study, nine piezometers consisting of $3 \mathrm{~cm}$ diameter pipes were installed at depths ranging from $2 \mathrm{~m}$ to $6.6 \mathrm{~m}$ (Table 1) to measure fluctuation in the subsurface water level.

Table 1. Installation Depth of Piezometers

\begin{tabular}{|c|c|c|c|c|c|c|c|c|c|}
\hline ID & PZ 01 & PZ 02 & PZ 03 & PZ 04 & PZ 05 & PZ 06 & PZ 07 & PZ 08 & PZ 09 \\
\hline Depth $(\mathrm{cm})$ & 641.50 & 298.10 & 542.80 & 345.90 & 572.80 & 425.10 & 356.00 & 577.00 & 664.00 \\
\hline
\end{tabular}

The piezometers installed consisted of PVC pipes, and a screen was placed at their perforated bottom to reduce sediment clogging. The researcher documented the daily water level in the piezometers using a sounding device (plopper) attached to a measuring tape. The sounding device is a small tube $17 \mathrm{~mm}$ in diameter and closed on one side; when the open end touches the water level, a "plopping sound" indicates the level of subsurface water from the surface. The measured water levels in the piezometers served as an input to calculate the vertical hydraulic gradient (VHG) (Figure 2). The VHG is an index used to measure the magnitude of groundwater table fluctuation; by noting the difference between the hydraulic head divided by the depth to the piezometer screen (Duval and Hill, 2006). For interpretation, a positive VHG indicates an upward flow into the wetland, while a negative indicates drawdown, and these have implications for recharge and soil water retention.

\section{Model Setup}

For the model setup, the atmospheric boundary condition with the surface layer specified is to allow the build-up of water, influenced by rainfall, evaporation, and infiltration. The upper boundary condition represented the daily rainfall measured with a HOBO tipping bucket. Using data from the Navrongo synoptic weather station actual evapotranspiration (ETa), as depicted in figure 5, was estimated using the modified Penman-Monteith algorithm (Allen et al.,1998). A 2-step approach to calculate actual evapotranspiration (Gong et al. 2006) was adopted; this 
involved calculating reference evapotranspiration (ETo) and then using a crop coefficient (Kc). The PenmanMonteith approach is composed of parameters that govern energy exchange and corresponding latent heat flux (evapotranspiration) from uniform vegetation. However, in developing countries such as Ghana, climate data are limiting factors; hence using PM parameters can either be measured or estimated using weather data as input. (Li et al., 2012; Rahimikhoob et al., 2012). Therefore daily ETo was estimated using the FAO 56 PM equation (Allen et al., 1998):

$$
E T_{o}=\frac{0.408 \Delta\left(R_{n}-G\right)+\gamma \frac{900}{T+273} U_{2}\left(e_{s}-e_{a}\right)}{\Delta+\gamma\left(1+0.34 U_{2}\right)}
$$

Where

$\mathrm{ET}_{\mathrm{o}}$ represents reference evapotranspiration ( $\left.\mathrm{mm} / \mathrm{day}\right)$;

$\mathrm{R}_{\mathrm{n}}$ is the net radiation at the crop surface $\left(\mathrm{MJ} \mathrm{m}^{-2}\right.$ day $\left.^{-1}\right)$, estimated according to the procedures outlined by Allen et al. (1998);

$\mathrm{G}$ is the soil heat-flux density ( $\mathrm{MJ} \mathrm{m}^{-2} /$ day), assumed as zero for daily calculations according to Allen et al. (1998);

$\mathrm{T}$ is the mean daily air temperature $\left({ }^{\circ} \mathrm{C}\right)$ at the height of $2 \mathrm{~m}$;

$\mathrm{u}_{2}$ is the wind speed at the height of $2 \mathrm{~m}(\mathrm{~m} / \mathrm{s})$;

$\mathrm{e}_{\mathrm{s}}$ is the saturation vapor pressure $(\mathrm{kPa})$;

$\mathrm{e}_{\mathrm{a}}$ is the actual vapor pressure $(\mathrm{kPa})$, which is based on relative humidity measurements;

$\left(\mathrm{e}_{\mathrm{s}}-\mathrm{e}_{\mathrm{a}}\right)$ is the saturation vapor pressure deficit (VPD) $(\mathrm{kPa}) ; \Delta$ is the slope of the vapor pressure curve $\left(\mathrm{kPa}^{\circ} \mathrm{C}^{-1}\right)$; and

$\gamma$ is the psychrometric constant $\left(\mathrm{kPa}^{\circ} \mathrm{C}^{-1}\right)$.

$$
\mathrm{ET}_{\mathrm{a}}=\mathrm{K}_{\mathrm{c}} \cdot \mathrm{ET}_{\mathrm{o}}
$$

Where

$\mathrm{ET}_{\mathrm{a}}$ is actual evapotranspiration ( $\mathrm{mm} /$ day) and $\mathrm{K}_{\mathrm{c}}$ - Crop reference.

At the lower boundary, the researcher specified free drainage, because, for the more significant part of the year, the groundwater level in the wetland is between $0.25 \mathrm{~m}$ and $15 \mathrm{~m}$ below the surface. However, groundwater levels vary spatially within the wetland. Soil hydraulic properties (Table 2) consisted of four layers of the soil profile. The data specified fitted into the finite element difference scheme used by Hydrus-1D to simulate flow processes. For each layer, van Genuchten parameters and hydraulic properties were assigned (Table 2).

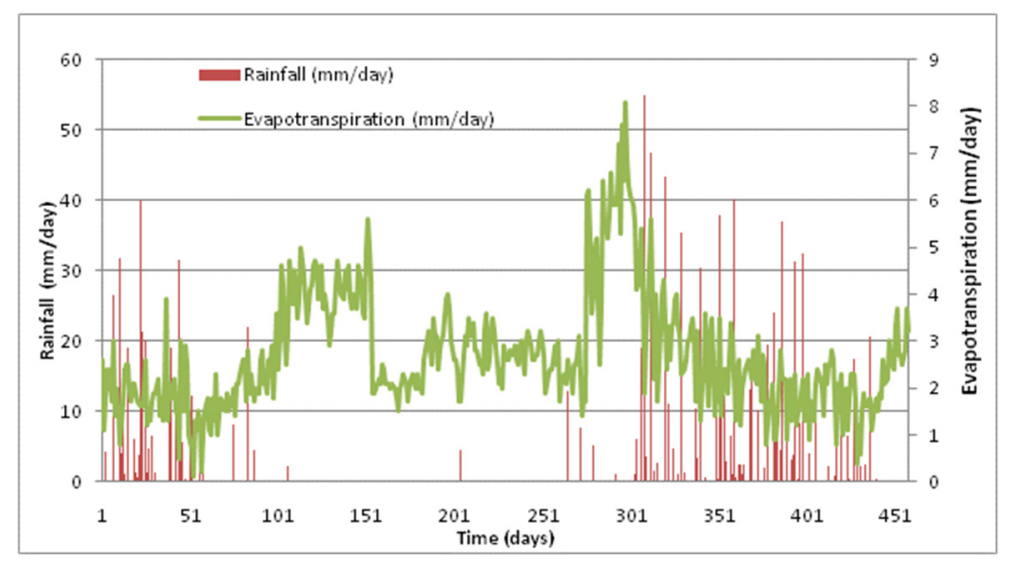

Figure 5. Daily rainfall and ETa values used in the HYDRUS-1D for the simulated period

\subsection{Model Calibration and Assessment}

The model result was calibrated and validated by comparing the simulated and field observed soil moisture at different depths. An index of agreement quantitatively assessed agreement between simulated and observed values, and root mean square error (RMSE). The root mean squared error (RMSE) was used to evaluate the predictive 
ability of the model. The RMSE quantifies the error or difference between the observed and predicted values. This difference helps to derive valuable information about the nature of the error. The units of RMSE is the same as the predicted and observed values. The equation expressed as:

$$
R M S E=\sqrt{\frac{\sum_{i=1}^{n}\left(P_{i}-O_{i}\right)^{2}}{N}}
$$

where $\mathrm{N}$ is the number of paired observations, $\mathrm{P}$ is the predicted value, and $\mathrm{O}$ is the observed value.

Another model diagnostic parameter is the index of agreement (d) (Mulligan and Wainwright, 2004). The index of agreement a dimensionless value gives an overall assessment of the prediction accuracy by describing the degree to which $\mathrm{O}$ approaches $\mathrm{P}$. The equation for index of agreement is:

$$
d=1-\left[\frac{\sum_{i=1}^{N}\left|P_{i}-O_{i}\right|}{\sum_{i=1}^{N}\left[\left(P_{i}-\bar{O}\right)+\left(O_{i}-\bar{O}\right)\right]}\right]
$$

\section{Results and Discussion}

\subsection{Initial Subsurface Water Level Variability}

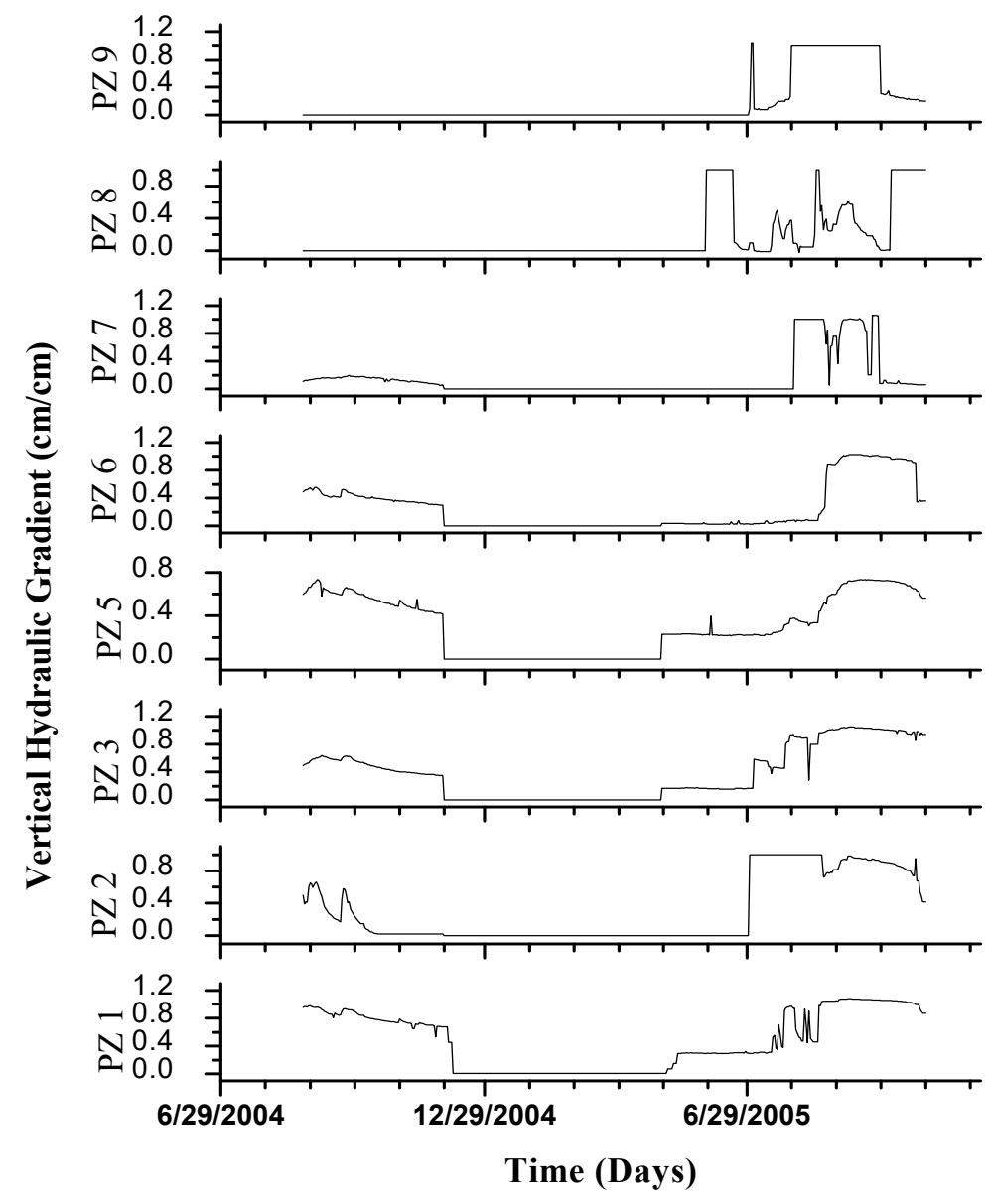

Figure 6. Vertical hydraulic gradient (VHG) of selected wells in the Pwalugu wetland site, to indicate the fluctuation of subsurface water within the rainfall year 
The subsurface water table measurement taken from the piezometers at the study site indicated a distinct and regular seasonal fluctuation. As indicated in Figure 4, the VHG showed a decrease in the dry season (NovemberMay). The level of subsurface water has dislocated deep below due to gravity, and this enhanced recharge. Every year, the water level was measured and recorded in all installed piezometers from July till November. From the estimate, a VHG of 0.4 and above is a good indicator of subsurface water rising to the surface. Variability of water fluxes and seasonal patterns were apparent across the entire wetland.

The network of piezometers provided an insight into a three-dimensional perspective of the pattern of the water table within the wetland. The calculated VHG (Figure 6) recharge occurs over all the floodplain wetlands, and the direction and magnitude of the gradients are essential. The magnitude of VHGs estimated (Figure 6) had semblance with the wetland subsurface water level. A critical examination of the VHG estimates shows that recharge appears to be the dominant interaction with subsurface water, though the order of magnitude was not estimated. A drop in water elevation across the wetland is a contribution to subsurface recharge. The measured water level at the lowest point of the wetland ranges between $3.0 \mathrm{~m}$ and $7.0 \mathrm{~m}$ and declines to between $3.0 \mathrm{~m}$ and $5.5 \mathrm{~m}$ on the southern and northern sides. Subsurface water levels along the White Volta River decline steadily, as the gradient is towards the main river.

The VHGs for PZ 1, PZ3, PZ8, and PZ9 are 0.47, 0.39, 0.16, and 0.18, respectively. PZ8 and PZ9, close to the main river course, have very low VHGs. The low VHG can be attributed to the high hydraulic gradient of groundwater from the riparian wetland to the main river (Spada et al., 2017; Liang et al., 2018) and invariably lower water table, so a larger unsaturated zone exists. Notably, recharge adds to water already stored in the soil, but the volume of storage and the subsurface water level influence it. The volume of soil water storage has a significant effect on the contribution of water from the floodplain wetland as baseflow to sustain the flow of the White Volta River in the wet and dry seasons (Nyarko, 2007).

\subsection{Model Parameters}

Within the wetland, at four different demarcated depths $(20 \mathrm{~cm}, 50 \mathrm{~cm}, 80 \mathrm{~cm}, 100 \mathrm{~cm})$ soil samples from 20 pits (Figure 1), were collected for analysis to understand the soil water movement. Parameters such as soil texture, bulk density, hydraulic conductivity, and soil water content were measured and served as inputs into the model. Also, because of the complexity of wetland eco-hydro-dynamics and the reduced level of instrumentation, a numerical model was adapted to capture details. Consequently, the HYDRUS-1D model adapted for this research is because of its ability to simulate the seasonal variation of water levels within unsaturated zones.

Table 2. Calibrated van Genuchten parameters (saturated soil water content $\left(\Theta_{s}\right)$, residual soil water content $\left(\Theta_{\mathrm{r}}\right)$ and coefficient $\alpha$ and exponent $n$ for soil water retention function), and saturated hydraulic conductivity

\begin{tabular}{lllllll}
\hline Site & Depth $(\mathrm{cm})$ & $\Theta_{\mathrm{s}}\left(\mathrm{cm}^{3} / \mathrm{cm}^{3}\right)$ & $\Theta_{\mathrm{r}}\left(\mathrm{cm}^{3} / \mathrm{cm}^{3}\right)$ & $\mathrm{A}(1 / \mathrm{cm})$ & $\mathrm{n}$ & Measured $\mathrm{K}_{\text {sat }}(\mathrm{cm} / \mathrm{day})$ \\
\hline Pit 1 & $0-20$ & 0.0799 & 0.4829 & 0.0137 & 1.2596 & 1.2572 \\
& $20-50$ & 0.0820 & 0.4848 & 0.0116 & 1.2348 & 77.2024 \\
& $50-80$ & 0.0839 & 0.4943 & 0.0147 & 1.2165 & 30.4318 \\
& $80-100$ & 0.0696 & 0.4337 & 0.0119 & 1.2694 & 0.7348 \\
Pit 2 & $0-20$ & 0.0776 & 0.4666 & 0.0117 & 1.2461 & 80.0460 \\
& $20-50$ & 0.0745 & 0.4566 & 0.0065 & 1.3319 & 95.9068 \\
& $50-80$ & 0.0685 & 0.4390 & 0.0088 & 1.3288 & 2.3418 \\
& $80-100$ & 0.0599 & 0.4045 & 0.0093 & 1.3280 & 1.7405 \\
Pit 6 & $0-20$ & 0.0280 & 0.4108 & 0.0110 & 1.4648 & 1.6447 \\
& $20-50$ & 0.0442 & 0.3885 & 0.0094 & 1.3962 & 2.5616 \\
& $50-80$ & 0.0528 & 0.4137 & 0.0155 & 1.3642 & 7.7770 \\
& $80-100$ & 0.0431 & 0.3713 & 0.0123 & 1.3615 & 1.4746 \\
Pit 7 & $0-20$ & 0.0574 & 0.4400 & 0.0213 & 1.3564 & 1.6081 \\
& $20-50$ & 0.0347 & 0.3780 & 0.0077 & 1.4262 & 1.8674 \\
& $50-80$ & 0.0487 & 0.4072 & 0.0104 & 1.3983 & 1.4969 \\
& $80-100$ & 0.0532 & 0.4070 & 0.0348 & 1.3423 & 2.0852 \\
\hline
\end{tabular}

The input data into the HYDRUS-1D model were: rainfall, evapotranspiration (Figure 5), number of layers in the soil profile, initial soil moisture condition (Figure 4), saturated water contents of each soil layer and initial water table depth, residual and, parameters $\alpha$ and $n$ (coefficient and exponent respectively in the soil water retention 
function), and the saturated hydraulic conductivity of each soil layer. The soil hydraulic properties are parameters given by van Genuchten for each cross-section (Table 2). At the same time, $K_{s}$ was measured in the laboratory using the falling head method, as described in Agyare (2004) and Nyarko (2007).

\subsection{Model Calibration Results}

The model run was for 457 days (August 2004 to October 2005), corresponding to the period when groundwater levels were measured. With input variables such as rainfall and evapotranspiration, the model simulation enabled the reproduction of seasonal variation of actual flux, bottom flux, storage volume, and ponding height at different locations. To depict level of water variations, Figure 8 shows observed and simulated water levels for selected piezometers. Table 2 shows selected statistical measures indicating the level at which the simulated and observed values agree. The high values signify that the predicted hydraulic heads had a high degree of agreement with the measured hydraulic head. The RMSE values estimated are to evaluate the predictive ability of the model. The index of agreement is a dimensionless value for the selected piezometers. An index value of above 0.90 is an indication that the overall assessment of the observed values' prediction accuracy approaches the simulated values.

Table 2. The statistical measure used to determine the good-of-fit between the field measures and the simulated water level in selected piezometers

\begin{tabular}{|c|c|c|c|c|c|}
\hline \multirow{2}{*}{\multicolumn{2}{|c|}{ Statistical measure }} & \multicolumn{4}{|c|}{ Values } \\
\hline & & $\mathbf{P}_{1}$ & $\mathbf{P}_{2}$ & $\mathbf{P}_{3}$ & $\mathbf{P}_{4}$ \\
\hline \multicolumn{2}{|c|}{ Index of Agreement $\mathrm{d}(0 \leq \mathrm{d} \leq 1)$} & 0.99 & 0.91 & 0.92 & 0.91 \\
\hline \multicolumn{2}{|c|}{ Root Mean Square Error } & 2.65 & 2.04 & 1.09 & 0.72 \\
\hline $\mathrm{P}_{1}$ & Piezometer 1 and Pit 1 & & & & \\
\hline $\mathrm{P}_{2}$ & Piezometer 3 and Pit 2 & & & & \\
\hline $\mathrm{P}_{3}$ & Piezometer 7 and Pit 7 & & & & \\
\hline $\mathrm{P}_{4}$ & Piezometer 9 and Pit 6 & & & & \\
\hline
\end{tabular}

Notably, the marked differences between observed and simulated water levels may be due to the uncertainty of the model, the heterogeneity exhibited by the soil, and observation errors encountered during the field measurement.

\subsection{Water Fluxes}

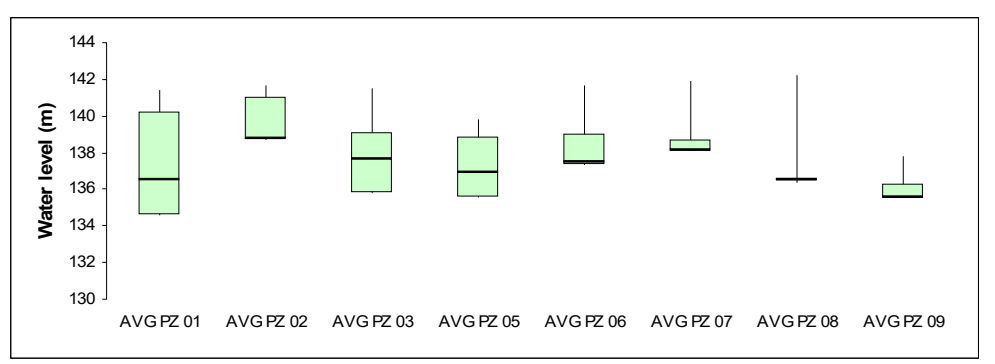

Figure 7. Box plot is the groundwater level fluctuation at the Pwalugu floodplain wetland site. The median is the thick line in the box, and the whiskers are the 10th and 90th percentiles

The model results gives a vivid account of recharge and the amplitude of the subsurface water level. For instance, a rainfall value of $76.3 \mathrm{~mm}$ in August 2006 as an input into the wetland, Pit 1 produced a bottom flux of about $0.73 \mathrm{~cm}^{-3}$ of water; however, Pit 6 , close to the main river channel, produced a flux of about $0.96 \mathrm{~cm}^{-3}$. As observed during the study period, the hydrodynamics within the wetland showed a marked variation. In 2005, the average simulated bottom flux estimated is $0.29 \mathrm{~cm}^{-3}$ in June and $1.23 \mathrm{~cm}^{-3}$ in July; consequently, the hydraulic head increased by $0.36 \mathrm{~m}$, which is from $138.94 \mathrm{~m}$ to $139.30 \mathrm{~m}$ for June and July 2005 . Figure 8 , the simulated results of HYDRUS-1D, shows the spatial variation in the contribution of recharge into subsurface or groundwater systems. For all sample sites, the increase in the hydraulic head occurs from July to October, coinciding with high 
surface water fluxes. The contrasting dynamics in the wetland suggest heterogeneity in soil hydraulic properties (Duval and Hill, 2006). Two essential soil hydraulic properties identified to control water fluxes, namely are water retention and unsaturated hydraulic conductivity (Sherlock et al., 2000; Simunek et al., 2016). Therefore it could also be deduced that physical processes such as water entrapment and pore blockage effectively decrease both cumulative drainage and the drainage rate.
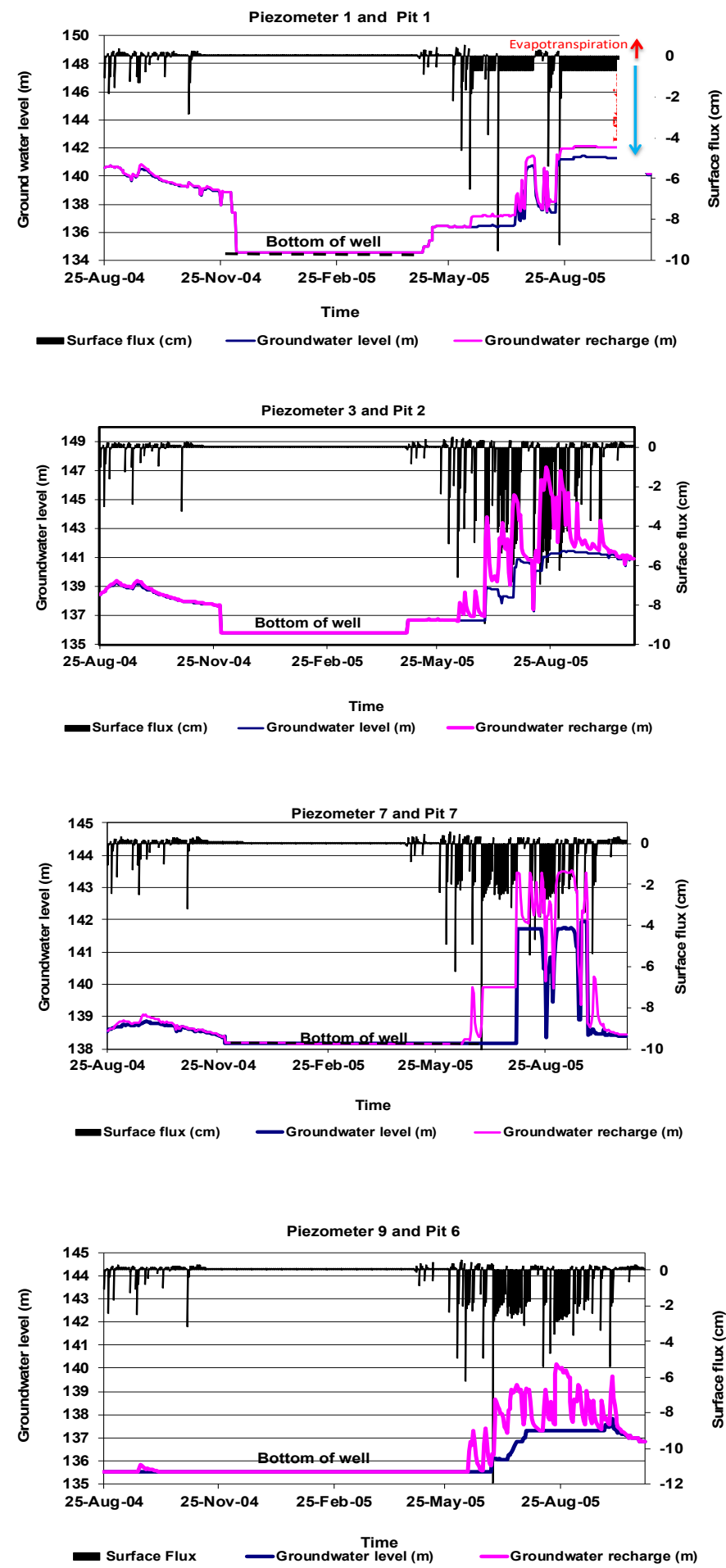

Figure 8. Measured and simulated hydraulic head of selected sites showing variability of subsurface recharge in the Pwalugu floodplain wetland 
Per the model results, storage volume of each sampled location differs due to fluxes and soil columns storage capacities (Sun et al., 1998), because from August 2004 to October 2015 soils in the floodplain had high potential fluxes but with different actual fluxes. Based on the results, the HYDRUS-1D as a tool, has the potential to evaluate the effect of changes in external boundary conditions such as rainfall and actual evapotranspiration on groundwater recharge and extraction.

Using the box plots (Figure 7), the study authenticated the level of variation between wells over the 433 days by comparing measured groundwater levels to the median of the water level. The median range fluctuated between $135.5 \mathrm{~m}$ and $138.73 \mathrm{~m}$. The measured water level in the wells fluctuated between $2.285 \mathrm{~m}$ and $6.87 \mathrm{~m}$. The variance in fluctuation was contingent on the rate at which soil hydraulic properties respond to rainfall input. For instance, PZ01 measured a water level with a variance of 7.04 as a coefficient of variation of 1.93 , indicating a response rate higher than PZ08, which is close to the White Volta River channel and had a variance of 0.72 and coefficient of variation of 0.62 . The water level fluctuations in the piezometers is skewed towards rainfall event, except PZ01 and PZ05 had a skewness of 0.16 and 0.19 , respectively, indicating that these wells had some water throughout the year.

\subsection{Water Balance and Groundwater Contribution}

The sources that contribute water to the wetland are direct rainfall, groundwater upwelling, and overbank flow from the Volta River. Water balance in floodplain wetlands are rarely quantified to provide information for floodplain water management or any form of irrigation related activities. Within the unsaturated zone of the wetland, the researcher estimated a water balance between September 2004 and December 2005 (Tables 3 and 4). The motive for generating a monthly water balance is that it is an essential step in relating available water resources with the hydrological requirements for different uses. Groundwater and water in the unsaturated zones play a role in soil moisture replenishment, vegetation growth, and transpiration.

The HYDRUS model's water balance computations were for specified times in each subregion of the flow domain. In the subregion, computed water balance information consists of the actual volume of water, and inflow or outflow. The model evaluates water contents at the corner nodes of the element, volumes of water in the subregion computed at the current and previous time levels, respectively, and summed up.

Table 3. Simulated annual water balance for soil profile in the Pwalugu wetland

\begin{tabular}{lllll}
\hline Time & $\begin{array}{l}\text { In-flow of water }\left[\mathrm{mm} \mathrm{yr}^{-}\right. \\
\left.{ }^{1}\right]\end{array}$ & $\begin{array}{l}\text { Potential } \\
\text { Evapotranspiration } \\
{\left[\mathrm{mm} \mathrm{yr}^{-1}\right]}\end{array}$ & $\begin{array}{l}\text { Actual surface } \\
\text { flux } \\
{\left[\mathrm{mm} \mathrm{yr}^{-1}\right]}\end{array}$ & $\begin{array}{l}\text { Groundwater } \\
\text { recharge } \\
{\left[\mathrm{mm} \mathrm{yr}^{-1}\right]}\end{array}$ \\
\hline 2004 & 685 & 342 & 174 & 169 \\
2005 & 1996 & 1093 & 627 & 276 \\
Total & 2334 & 1436 & 453 & 445 \\
\hline
\end{tabular}

Table 4. Simulated water balance for selected months at the Pwalugu wetland site

\begin{tabular}{|c|c|c|c|c|c|}
\hline Time & $\begin{array}{l}\text { Inflow of water } \\
{[\mathrm{mm} / \text { month }]}\end{array}$ & $\begin{array}{ll}\text { Potential evapotranspiration } \\
{[\mathrm{mm} / \mathrm{month}]}\end{array}$ & $\begin{array}{l}\text { Actual surface flux } \\
{[\mathrm{mm} / \mathrm{month}]}\end{array}$ & $\begin{array}{l}\text { Groundwater } \\
{[\mathrm{mm} / \mathrm{month}]}\end{array}$ & recharge \\
\hline Sep-04 & 152 & 48 & 56 & 48 & \\
\hline Nov-04 & 175 & 109 & 27 & 39 & \\
\hline May-05 & 190 & 170 & 12 & 8 & \\
\hline Jul-05 & 94 & 74 & 14 & 6 & \\
\hline Sep-05 & 157 & 57 & 53 & 47 & \\
\hline Nov-05 & 170 & 122 & 37 & 11 & \\
\hline Mean & 156.33 & 96.67 & 33.17 & 26.50 & \\
\hline Std Dev. & 33.39 & 46.10 & 18.88 & 20.21 & \\
\hline $\begin{array}{l}\text { Coeff. } \\
\text { Var. }\end{array}$ & 21.36 & 47.69 & 56.93 & 76.25 & \\
\hline
\end{tabular}

From Table 4, the seasonal variation in water storage in the unsaturated zone can be observed. However, the amount of water that the floodplain wetland receives includes direct rainfall, surface runoff, and overbank flow. The volume of water in the wetland reflects actual surface flux, groundwater recharge, and soil water storage; these are stochastic (Tamea et al., 2010; Simunek et al., 2016) and seasonal patterns of water level fluctuation in 
the wetland. In their work, Joris and Feyen (2003) noted that wetlands display a feedback mechanism that can offset moisture stress during the dry period. Within the HYDRUS-1D model for September 2004 and September 2005, an inflow of $152 \mathrm{~mm}$ and $157 \mathrm{~mm}$ corresponded to a simulated groundwater recharge of $48 \mathrm{~mm}$ and $47 \mathrm{~mm}$, respectively. A groundwater recharge above $6 \mathrm{~mm}$ correlates with a significant amount of water input. November through to May records high evaporative values; hence the subsurface water system receives no water input. On an annual basis, the contribution of groundwater recharge (Table 4), on average, is $169 \mathrm{~mm}$ yr-1 and $276 \mathrm{~mm}$ yr1 for the years 2004 and 2005, respectively.

The Pwalugu wetland is characterized by spatial and temporal variability of water inflows and outflows, as depicted in figure 8 . The flux within the wetland is also controlled by the hydraulic gradient that generates a rapid flux, which is bidirectional, regardless of the soil structure (Riddell et al., 2012). For most parts of the year, the unsaturated zone stores a significant portion of infiltrated rainfall and subsequently redistributes the stored water into the subsurface. In most cases, farmers operating irrigation systems have to dig wells to a depth of 6-8 $\mathrm{m}$ to reach an appreciable volume of water, which adds to the cost of their investment. As of 2004 and 2005, during dry season irrigation activities, two distinct growing stages have been identified when pumped water from the river and hand-dug wells are needed most; they are the growing and flowering stages. In the application of water to irrigate cultivated crops, most of the farmers practice flooded irrigation.

In most cases, the application of water to a plot is until the soil is saturated, and its duration depends on the farmers' experience. Some farmers may apply water to the crops every other day while other farmers do it when they observe a moisture deficit in the soil. Starting from October, for six(6) weeks, an estimated average of $5.53 \mathrm{~mm} /$ day is extracted and applied per square meter of the plot during the planting and growing stages of the crop. At the flowering stage, $9.50 \mathrm{~mm} /$ day of water is use to irrigate per square meter of the plot, and that lasts until the products have matured. During the dry season, an estimated $2180 \mathrm{~m}^{2}$ to $3600 \mathrm{~m}^{2}$ of land is under cultivation.

The fractional contribution of recharge into the subsurface system varies spatially in the amount of bottom water flux at different wetlands sections. As per the model results, Pit 1 recorded a flux of about $0.73 \mathrm{~cm} / \mathrm{month}$ of water in August 2005, while Pit 6, near the main river channel, had a flux of about $0.96 \mathrm{~cm} / \mathrm{month}$. The recorded average bottom flux of $0.29 \mathrm{~cm} /$ month and $1.23 \mathrm{~cm} /$ month was in June 2005 and July 2005 . The vertical fluxes into the subsurface increased the average hydraulic head from $138.94 \mathrm{~m}$ in June 2005 to $139.30 \mathrm{~m}$ in July 2005 . Groundwater upwelling as a result of the increased hydraulic head occurred between July and October, where recharge from the unsaturated zone peaked. Also, subsurface recharge varied seasonally, from July to October in 2005, giving a higher contribution. In 2004 the rainfall pattern was not regular, thus affecting the subsurface water contribution pattern. From the calculated water balance, the average monthly estimate of bottom flux was 0.01 $\mathrm{cm} /$ month for 2004 and $1.1 \mathrm{~cm} /$ month for 2005 .

Another point worthy of note is that within the wetlands, the variation in topography and subsurface slope towards the main White Volta River exerts a significant influence over subsurface recharge. The extraction of water from any part of the wetlands for irrigation purposes appeared to have a substantial effect on the direction of vertical flux, thereby causing relatively rapid reversals between recharge and discharge (Duval and Hill, 2006).

\section{Conclusion}

This study is to simulate the flow within the vadose zone into the subsurface for a layered soil profile using HYDRUS-1D. The vadose zone represented as an utterly porous medium but has different characteristics, but changes within the floodplains landscape can create the next recharge and discharge zones. The model predicted flow at different water input periods. The presence of high permeability materials within the wetland layers permitted the creation of a local flow cell into the subsurface. In sections of the wetland, lower layers consisting of aquitard do impede the flow into the subsurface, thereby creating a ponded surface. The HYDRUS-1D model enabled the estimation of the seasonal variation of recharge. Before any decision to use the floodplain wetland for agriculture activity, it is essential to understand the hydrodynamics setting. The results indicate a spatial and temporal variation in groundwater recharge, which should be part of any floodplain management scheme. Therefore, it holds the key to the management of irrigation activities and improving water productivity on the White Volta River basin's floodplain wetland. Improving water productivity is one vital strategy to alleviate water scarcity within the basin. The scarcity of water is most likely to be determined by the expansion of irrigated plots due to population growth and to climate and land-use change.

Consequently, much education on improving water productivity with smallholder schemes will reduce competition for scarce water resources, mitigate environmental degradation and enhance food security. Hence, producing more food with less water makes more water available for other natural and human uses (Rijsberman \& Molden, 2001). Knowledge of the hydrodynamics of wetlands in the Volta River basin improves our understanding of wetland 
components and how they interact with our environment. From the study, hydraulic gradient induce bidirectional flow, but there is a need to investigate how it contributes to soil moisture replenishment and vegetation dynamics.

\section{Acknowledgments}

The author wishes to thank the numerous field assistants who contributed to the collection of the data. Funding from the German Ministry of Education and Research (BMBF), the GLOWA-Volta Project and the Centre for Development Research (ZEF), Germany, which enabled him to pursue this research as part of his Ph.D. degree programme, is gratefully acknowledged.

\section{Funding}

The work presented is part of the Ph.D. research work of the author. It was funded by the German Ministry of Education and Research (BMBF) through the GLOWA-Volta Project and the Centre for Development Research (ZEF), Germany.

\section{Conflict of interests}

The authors declare that there is no conflict of interests regarding the publication of this paper.

\section{References}

Agyare, W. A. (2004). Soil characterization and modeling of spatial distribution of saturated hydraulic conductivity at two sites in the Volta basin of Ghana. PhD Thesis, Centre for Development Research, University of Bonn, Bonn, Germany.

Allen, R. G., Pereira, L. S., Raes, D., \& Smith, M. (1998). Crop evapotranspiration - Guidelines for computing crop water requirements - FAO irrigation and drainage paper 56, FAO - Food and Agriculture Organization of the United Nations, Rome.

Bradley, C., \& Gilvear, D. J. (2000). Saturated and unsaturated flow dynamics in a floodplain wetland. Hydrol Process, $\quad 14$ 2945-2958. https://doi.org/10.1002/1099-1085(200011/12)14:16/17<2945::AIDHYP128>3.0.CO;2-R

Brown, T. N., Johnston, C. A., \& Cahow, K. R. (2003). Lateral flow routing into a wetland: Field and model perspectives. Geomorphology, 53, 11-23. https://doi.org/10.1016/S0169-555X(02)00345-8

Duval, T. P., \& Hill, A. R. (2006). Influence of stream bank seepage during low-flow conditions on riparian zone hydrology. Water Resources Research, 42, W10425. https://doi.org/10.1029/2006WR004861

Gong, L., Xu, C., Chen, D., Halldin, S., \& Chen, Y. (2006). Sensitivity of the Penman-Monteith reference evapotranspiration to key climatic variables in the Changjiang (Yangtze River) basin. Journal of Hydrology, 329(3-4), 620-629. https://doi.org/10.1016/j.jhydrol.2006.03.027

House, A. R., Thompson, J. R., Sorensen, J. P. R., Roberts, C., \& Acreman, M. C. (2016). Modelling groundwater/surface water interaction in a managed riparian chalk valley wetland. Hydrol. Process., 30, 447462. https://doi.org/10.1002/hyp.10625

Joris, I., \& Feyen, J. (2003). Modelling water flow and seasonal soil moisture dynamics in an alluvial groundwaterfed wetland. Hydrol Earth Syst Sci, 7(1), 56-66. https://doi.org/10.5194/hess-7-57-2003

Kesse, G. O. (1985). The mineral and rock resources of Ghana. Rotterdam: Balkema Publishers.

Li, Z., Zheng, F.-L., \& Liu, W.-Z. (2012). Spatiotemporal characteristics of reference evapotranspiration during 1961-2009 and its projected changes during 2011-2099 on the Loess Plateau of China. Agricultural and Forest Meteorology, 154-155, 147-155. https://doi.org/10.1016/j.agrformet.2011.10.019

Liang, X., Zhan, H., \& Schilling, K. (2018). Spatiotemporal responses of groundwater flow and aquifer-river exchanges to flood events. Water Resources Research. https://doi.org/10.1002/2017WR022046

Mansell, R. S., Bloom, S. A., \& Ge, S. (2000). A model for wetland hydrology: Description and validation. Soil Science, 165, 5. https://doi.org/10.1097/00010694-200005000-00002

Mertes, L. A. K. (1997). Documentation and significance of perirheic zone on inundated floodplains. Water Resources Research, 33, 1749-1762. https://doi.org/10.1029/97WR00658

Mulligan, M., \& Wainwright, J. (2004). Modeling and model building. In J. Wainwright, \& M. Mulligan (Eds.), Environmental modelling: Finding simplicity in complexity (pp. 187-196). Chichester: John Wiley and Sons.

Nyarko, B. K. (2007) Floodplain wetland riverflow synergy in the White Volta River Basin, Ghana. Ecology and Development Series, Bd. No. 53. 
Rahimikhoob, A., Behbahani, M. R., \& Fakheri, J. (2012). An evaluation of four reference evapotranspiration models in a subtropical climate. Water Resources Management, 26(10), $2867-2881$. https://doi.org/10.1007/s11269-012-0054-9

Ravi, V., Williams, J. R., \& Burden, D. S. (1998). Estimation of infiltration rate in the vadose zone: Compilation of simple mathematical models Volume I, U.S. Environmental Protection Agency, EPA/600/R-97/128a.

Riddell, E. S., Lorentz, S. A., \& Kotze, D. C. (2012). The hydrodynamic response of a semi-arid headwater wetland to technical rehabilitation interventions. Water $S A$, 38(1). https://doi.org/10.4314/wsa.v38i1.8

Rijsberman, F. R., \& Molden, D. (2001). Balancing water uses: Water for food and water for nature, thematic background paper. International conference on freshwater, Bonn, 18 . Retrieved from http://www.iiav.nl/epublications/2001/balancing_water_uses.pdf

Sherlock, M. D., Chappell, N. A., \& McDonnell, J. J. (2000). Effects of experimental uncertainty on the calculation of hillslope flow paths. Hydrological Processes, 14(14), 2457-2471. https://doi.org/10.1002/10991085(20001015)14:14<2457::AID-HYP106>3.0.CO;2-I

Simunek et al. (1998). Parameter estimation of unsaturated soil hydraulic properties from transient flow processes. Soil and Tillage Research, 47, 27-36. https://doi.org/10.1016/S0167-1987(98)00069-5

Simunek, J., van Genuchten, M. T., \& Gribb, M. M. (1996). Estimating unsaturated soil hydraulic properties from tension disc infiltrometer data by numerical inversion. Water Resources Research, 32(9), 2683-2696. https://doi.org/10.1029/96WR01525

Simunek, J., van Genuchten, M. T., \& Šejna, M. (2016). Recent developments and applications of the HYDRUS computer software packages. Vadose Zone Journal, 15(7). https://doi.org/10.2136/vzj2016.04.0033

Spada, E., Sinagra, M., Tucciarelli, T., Barbetta, S., Moramarco, T., \& Corato, G. (2017). Assessment of river flow with significant lateral inflow through reverse routing modeling. Hydrological Processes, 31, 1539-1557. https://doi.org/10.1002/hyp.11125

Sriwongsitanon, N., Surakit, K., \& Hawkins, P. R. (2009). A water balance budget for Bung Boraphet - A flood plain wetland-reservoir complex in Thailand. Water, 1, 54-79. https://doi.org/10.3390/w1010054

Sun, G. H., Riekerk, H., \& Commerford, N. B. (1998). Modeling the forest hydrology of wetland-upland ecosystems in Florida. J. Am. Water Res. Assoc, 34, 827-841. https://doi.org/10.1111/j.17521688.1998.tb01519.x

Tamea, S., Muneepeerakul, R., Laio, F., Ridolfi, L., \& Rodriguez-Iturbe, I. (2010). Stochastic description of water table fluctuations in wetlands. Geophysical Research Letters, 37, L06403. https://doi.org/10.1029/2009GL041633

Trepel, M., \& Kluge, W. (2004). WETTRANS: a flow-path-oriented decision-support system for the assessment of water and nitrogen exchange in riparian peat lands. Hydrol. Process, 18, $357-371$. https://doi.org/10.1002/hyp.1380

Vogel, H. J., \& Ippisch, O. (2006). Estimation of a critical spatial discretization limit for solving Richards' Equation at large scales. Vadose Zone Journal, 7(1), 112-114. https://doi.org/10.2136/vzj2006.0182

Wang, Q., Zhang, J., \& Fan, J. (2006). An analytical method for relationship between hydraulic diffusivity and soil sorptivity. Pedosphere, 16(4), 444-450. https://doi.org/10.1016/S1002-0160(06)60074-X

Woessner, W. (2000). Stream and fluvial plain groundwater interaction; rescaling hydrogeological thought. Groundwater, 38(3), 423-429. https://doi.org/10.1111/j.1745-6584.2000.tb00228.x

\section{Copyrights}

Copyright for this article is retained by the author(s), with first publication rights granted to the journal.

This is an open-access article distributed under the terms and conditions of the Creative Commons Attribution license (http://creativecommons.org/licenses/by/4.0/). 